\title{
Environmental variables, pesticide pollution and meiofaunal community structure in two contrasting temporarily open/ closed False Bay estuaries
}

\author{
S Bollmohr ${ }^{1,2 *}$, PJ van den Brink ${ }^{3,4}$, PW Wade ${ }^{5}$, JA Day ${ }^{6}$ and R Schulz ${ }^{2}$ \\ ${ }^{1}$ Zoology Department, University of Johannesburg, 2006 Auckland Park, Johannesburg, South Africa \\ ${ }^{2}$ Institute for Environmental Sciences, University Koblenz-Landau, D-76829 Landau/Pfalz, Germany \\ ${ }^{3}$ Alterra, Centre for Water and Climate, Wageningen University and Research Centre, PO Box 47, \\ 6700AA Wageningen, The Netherlands \\ ${ }^{4}$ Wageningen University, Department of Aquatic Ecology and Water Quality Management, Wageningen \\ University and Research Centre, PO Box 47, 6700AA Wageningen, The Netherlands \\ ${ }^{5}$ Environmental Geoscience Unit, Council for Geoscience, Private Bag X112, Pretoria, 0001, South Africa \\ ${ }^{6}$ Freshwater Research Unit, University of Cape Town, Private Bag, Rondebosch 7701, South Africa
}

\begin{abstract}
Environmental variables (including natural and anthropogenic stressors) and meiobenthic communities were sampled in a 'natural' (Rooiels) and a 'disturbed' (Lourens) estuary in the Western Cape, South Africa, bimonthly for 20 months. A primary aim of the study was to assess if the meiobenthic community structure is driven by different variables when comparing 'natural' versus 'disturbed' system. Due to the much smaller catchment of the Rooiels Estuary, many environmental variables were significantly different $(p<0.001)$ from the variables in the Lourens Estuary, e.g. salinity, temperature, $\mathrm{pH}$, total suspended solids, nitrate and depth. No pesticide concentrations were expected in the Rooiels Estuary due to the absence of agricultural development in the catchment. However, chlorpyrifos $(8.9 \mu \mathrm{g} / \mathrm{kg})$, prothiofos $(22.0 \mu \mathrm{g} / \mathrm{kg})$ and cypermethrin concentrations $(0.42 \mu \mathrm{g} / \mathrm{kg})$ were detected frequently, with the highest concentrations recorded during the summer months. Principal response curve analysis showed that temporal variability between sampling dates explained $42 \%$ of the variance in environmental variables and pesticide concentrations and spatial variability between the 2 estuaries explained $58 \%$. Variables contributing most to the differences were higher concentrations of endosulfan, p,p-DDE and nitrate concentrations in the Lourens Estuary and larger grain size and higher salinity at the bottom in the Rooiels Estuary. In general the meiofaunal community in the Rooiels Estuary showed a significantly higher number of taxa $(p<0.001)$, a significantly higher Shannon Wiener Diversity Index $(p<0.001)$ and a generally lower meiofaunal abundance with less variability than in the Lourens Estuary. The differences were mostly explained by a higher abundance of Cypretta and Darcythompsonia in the Rooiels Estuary and a higher abundance of Thermocyclops and Canthocamptus in the Lourens Estuary. The variables explaining a significant part (14\%) of the variance in meiofaunal abundance in the Rooiels Estuary were salinity and temperature, with the Redundancy Analysis indicating that the abundance of most of the taxa increased with higher salinity and temperature, e.g. Upogebia, Nereis, Uroma and nematodes were clearly positively correlated to salinity and temperature. The variables explaining a significant part of the variance in the dataset (43\%) within the Lourens Estuary were also salinity and temperature but included chlorpyrifos, nitrate and flow (including river and tidal flow).
\end{abstract}

Keywords: particle-associated insecticides; meiofauna; estuaries; South Africa

\section{Introduction}

Temporarily open/closed estuaries (TOCEs) are the dominant estuary type in South Africa, comprising $73 \%$ of all estuaries (Whitfield, 1995). Similar systems, sometimes referred to as 'blind', 'intermittently open', or 'seasonally open' estuaries, are also found in Australia, on the west coast of the USA, in South America and in India (Ranasinghe and Pattiaratchi, 1999). TOCEs are often closed off from the sea, and the lack of freshwater input and tidal exchange may result in changes in various physicochemical variables (e.g. salinity, temperature, flow) and anthropogenic stressors (e.g. pesticides). This spatial and temporal variability within TOCEs can have direct and indirect impacts on the biota (e.g. zooplankton, meiofauna, ichthyofauna, phytoplankton) (Kibirige and Perissinotto, 2003).

\footnotetext{
* To whom all correspondence should be addressed.

용 +2712 809-3787; fax: +2711 559 2286;

e-mail: silke.bollmohr@gmail.com

Received 20 October 2010; accepted in revised form 30 May 2011.
}

Limited long-term monitoring data exists for TOCEs, making it difficult to recognise the degree of variability in these estuaries and the factors influencing their communities. A few studies have sampled different variables on a monthly basis (Nozais et al., 2005, Kibirige and Perissinotto, 2003) and others on a seasonal basis over a period of up to a year (Perissinotto et al., 2000) or several years (James et al., 2008). These studies indicate that there is considerable temporal variability within these systems. The present study is one of the first to examine natural variables, anthropogenic stressors and community responses in such estuaries over a period of 2 years. One of the factors limiting our understanding of South African estuaries is the lack of long-term monitoring data. The National Water Act (Act No. 36 of 1998) in South Africa recognizes basic human water requirements as well as a need to sustain the country's freshwater and estuarine ecosystems in a healthy condition for present as well as future generations (Adams et al., 2002). A National River Monitoring Programme has been in place in South Africa for many years (DWAF, 2006) but no equivalent has yet been designed for estuaries. 


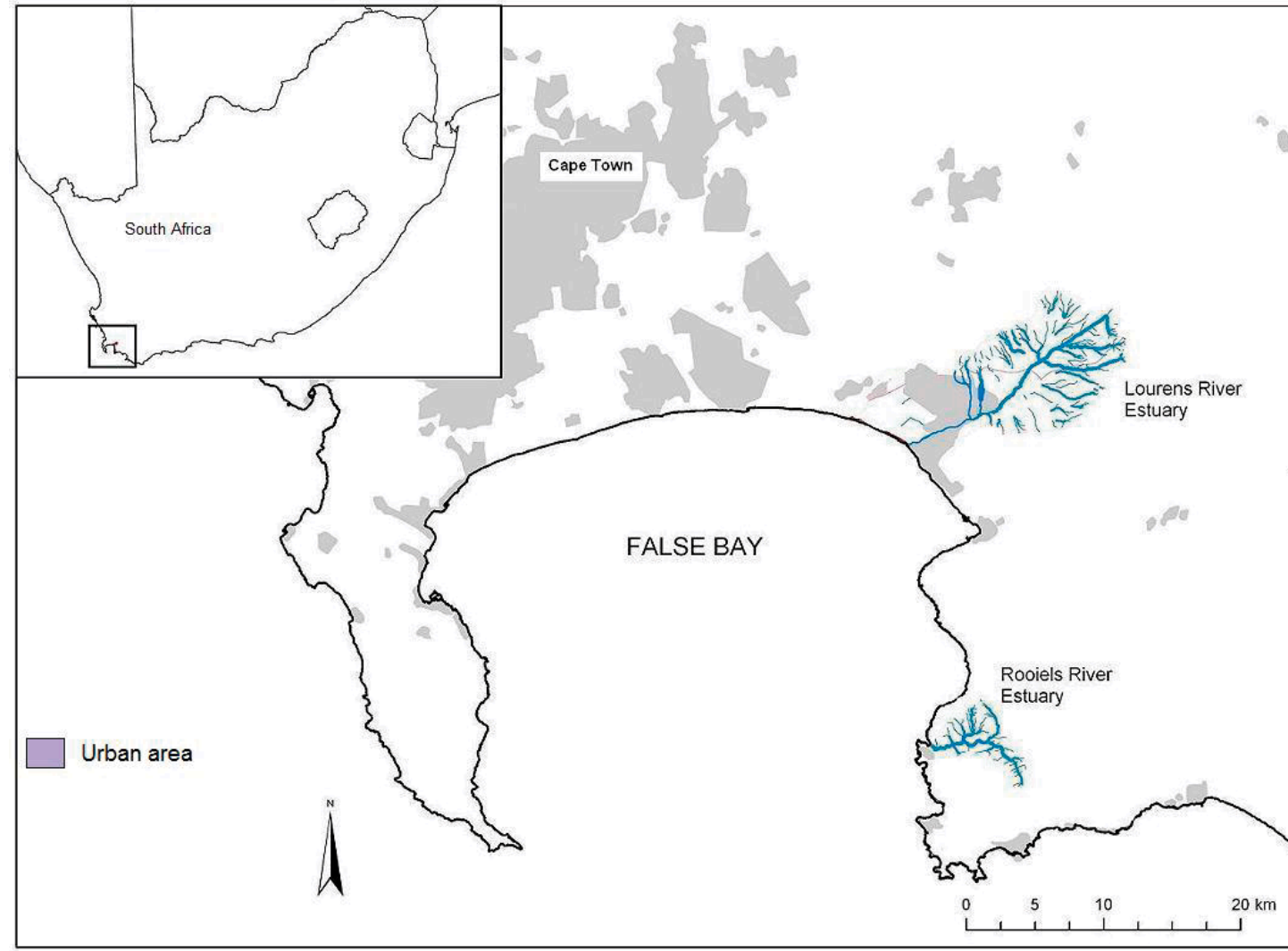

Figure 1

False Bay and the location of Lourens River and

Rooiels River estuaries

Many estuarine and coastal management initiatives worldwide (e.g. North America, Europe and Australia) are required to derive and use environmental quality indices; examples include implementation of the European Water Framework Directive and the UC Clean Water Act (Quintino et al., 2006). Those indices are then used to test for departure from a reference or control condition. Thus to be able to identify the impacts of anthropogenic stressors such as pesticides, it is important to understand the natural spatial and temporal variability in physical and chemical conditions and their impacts on community structure. It is therefore crucial to understand the driving variables by examining natural estuarine systems whose catchments are not associated with any anthropogenic activity. To achieve this, the dynamics of abiotic and biotic variables of a natural system need to be compared with those of a disturbed system using a multivariate approach such as the principal response curve (PRC). The PRC approach has been shown to be valuable in statistically analysing multiple endpoints (Van den Brink and Ter Braak, 1999) and has already been used for biomonitoring by Den Besten and Van den Brink (2005) and Van den Brink et al. (2009).

For the purposes of the current study the Lourens Estuary represents a disturbed system and the Rooiels Estuary an undisturbed or reference system. Previous research (Bollmohr and Schulz, 2009; Schulz et al., 2001) has shown that pesticides contribute significantly to the pollution and associated effects in the Lourens River. Particles entering the estuary are associated with high concentrations of chlorpyrifos $(19.6 \mu \mathrm{g} /$ $\mathrm{kg})$, endosulfan $(18.6 \mu \mathrm{g} / \mathrm{kg})$ and prothiofos $(34.0 \mu \mathrm{g} / \mathrm{kg})$ (Bollmohr et al., 2007), with highest concentrations occurring during the spring and summer season. The present study focused on changes in the epibenthic, hyperbenthic and demersal meiobenthos and zooplanktonic organisms living in the flocculent layer between the sediment and water column.
The importance of these organisms in anthropogenic stressor studies is discussed in Bollmohr et al. (2009c). International meiofaunal studies have tended to focus on community structure in relation to variables such as sediment composition (Sherman and Coull, 1980), salinity (Miliou, 1993) and food sources (e.g. Decho and Castenholz, 1986) that drive its composition. To ascertain the effect of pesticides on meiobenthic abundance, various studies have been performed using sediment toxicity tests (e.g. Chandler and Green, 2001; Bollmohr et al., 2009b) or microcosm experiments (Chandler et al., 1997) but only a few have used biomonitoring in the field (Warwick et al., 1990, Bollmohr et al., 2009c). Very few studies have focused on seasonal fluctuations in meiofauna or zooplankton in South African estuaries in relation to the distribution of physical factors (Nozais et al., 2005, Pillay and Perissinotto, 2009), the state of the mouth (Kibirige and Perissinotto, 2003) and food-web interactions (Perissinotto et al., 2000), and virtually no studies exist on pollutants (Bollmohr et al., 2007; Bollmohr et al., 2009c).

The aims of this study were twofold: To identify the driving environmental variables (including natural and anthropogenic stressors) in a reference and a disturbed system, and to identify the extent to which these variables reflect differences in meiofaunal assemblage structure within the flocculent layer.

\section{Material and methods}

\section{Study area}

The study took place in the False Bay region of the Western Cape Province, South Africa (Fig. 1), an area characterised by cool, wet winters and warm dry summers. Measurements within the 2 TOCE study sites occurred in the lower reaches of the estuaries and always during low tide. 


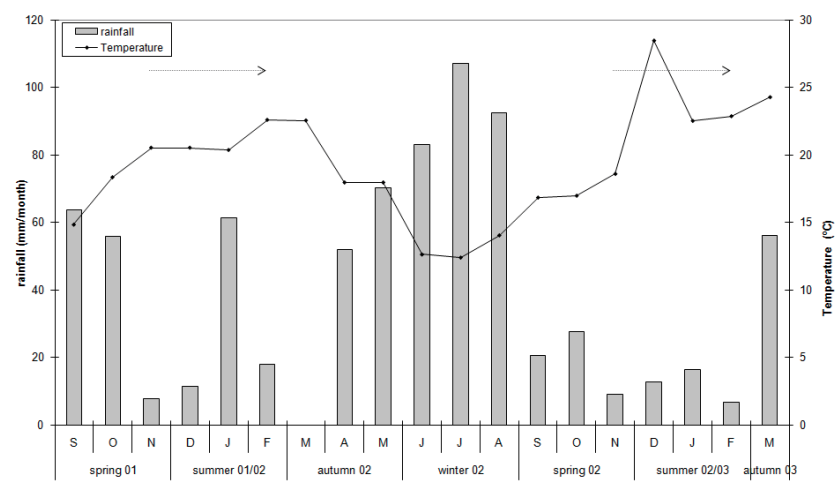

Figure 2

Monthly rainfall and temperature data (obtained from Verelegen weather station at $80 \mathrm{~m}$ altitude) during the study period (September 2001 to March 2003). The dotted lines indicated the spraying season of pesticides.

\section{The Lourens Estuary}

The Lourens Estuary mouth is located at $34^{\circ} 06^{\prime} \mathrm{S}$ and $18^{\circ} 49^{\prime} \mathrm{E}$; the river (20 km long) rises in the Hottentots Holland Mountains, flows through intensive agricultural areas, and the town of Somerset West, after which it enters False Bay at the Strand (Cliff and Grindley, 1982). The estuary is about $0.71 \mathrm{~km}^{2}$ in area with a tidal range of $1.48 \mathrm{~m}$. Mean annual runoff (MAR) is approximately $122 \times 10^{6} \mathrm{~m}^{3}$ (Whitfield and Bate, 2007). Land use in the Lourens River sub-catchment of $140 \mathrm{~km}^{2}$ comprises forestry, agriculture, residential areas and light industries. A large section of the upper catchment is privately-owned agricultural land with vineyards and apple, pear and plum orchards on which pesticide application takes place annually between August and February (Schulz, 2001).

\section{The Rooiels Estuary}

The Rooiels Estuary mouth is situated at $34^{\circ} 18^{\prime} \mathrm{S}$ and $18^{\circ} 49^{\prime} \mathrm{E}$, with a catchment that lies within the southern extension of the Hottentots Holland Mountain Reserve and flows through the Kogelberg Nature Reserve. The total distance from the river mouth to the end of the longest tributary is only $9 \mathrm{~km}$ (Whitfield and Bate, 2007). The estuary is about $0.122 \mathrm{~km}^{2}$ in area with a tidal range of $1.48 \mathrm{~m}$. The MAR is $10 \times 10^{6} \mathrm{~m}^{3}$ and the entire catchment $\left(21 \mathrm{~km}^{2}\right)$ lies within a nature reserve, with a small holiday resort located near the mouth (Heydorn and Grindley, 1982).

\section{Pesticide application and seasonal weather data}

The 20-month investigation from August 2001 to March 2003 included dry summer months (November to March) with infrequent rainfall (Fig. 2) and wet winter months from May to August. Organophosphates, such as chlorpyrifos (686 kg/ha) and prothiofos $(87 \mathrm{~kg} / \mathrm{ha})$, organochlorines such as endosulfan $(158 \mathrm{~kg} / \mathrm{ha})$ and pyrethroids such as cypermethrin $(8 \mathrm{~kg} / \mathrm{ha})$ and fenvalerate $(5 \mathrm{~kg} / \mathrm{ha})$, are frequently applied to pears, plums and apples between August and February before fruit is harvested (Dabrowski et al., 2002); frequency of application is highest during the dry summer season from November to January (Schulz, 2001) (dotted lines in Fig. 2).

\section{Physico-chemical measurements}

Various physicochemical parameters were measured every
2 weeks during the study period. Measurement always took place in the morning during low tide. The flow rate, which included the river flow and the ebb tidal flow, was measured every metre across each estuary using a flow meter (Höntzsch Co, Waiblingen, Germany) and the discharge towards the sea was calculated.

Dissolved oxygen, $\mathrm{pH}$, temperature and conductivity of the estuarine waters were measured with electronic meters from Wissenschaftliche Technische Werkstätten GmbH, Weilheim, Germany. Salinity was established by converting conductivity values into salinity using an automatic converter (Fofonoff and Millard, 1983). Total suspended solids (TSS) were measured with a turbidity meter (Dr Lange, Düsseldorf, Germany) and nutrients were measured using photometric test kits from Macherey \& Nagel, Düren, Germany. Total organic carbon (TOC) of the sediment was quantified by removal of all organic matter, followed by gravimetric determination of sample weight-loss (ASTM, 2000). Grain-size analysis was performed by dry-fraction sieving of sediment samples previously treated with hydrogen peroxide. Sediment was divided into 7 fractions: silt and clay $(<0.063 \mathrm{~mm})$, very fine sand ( 0.063 to $0.125 \mathrm{~mm}$ ), fine sand $(0.125$ to $0.25 \mathrm{~mm}$ ), medium sand $(0.25$ to $0.5 \mathrm{~mm})$, coarse sand $(0.5$ to $1 \mathrm{~mm})$, very coarse sand (1to $2 \mathrm{~mm}$ ) and gravel ( $>2 \mathrm{~mm}$ ). Each fraction was weighed and expressed as a percentage of the total mass. Four sediment samples (top $15 \mathrm{~cm}$ ) per site (within a $1 \mathrm{~m}^{2}$ transect) were taken for analysis.

Micro-algal biomass was determined in the water column and in the sediment by measuring the concentration of chlorophyll $a$. Four replicates of $2 \ell$ water samples were filtered through Whatman (GF/C) glass-fibre filters. The chlorophyll $a$ was extracted by grinding the filters with $10 \mathrm{~m} \ell$ of $99 \%$ acetone. After centrifuging, the light absorbance at $665 \mathrm{~nm}$ of the supernatant was determined before and after adding 2 drops of $0.1 \mathrm{~N} \mathrm{HCl}$. Chlorophyll $a$ concentrations were calculated using the equation of Hilmer (1990). Nine replicates of benthic micro-algal samples were taken within a $1 \mathrm{~m}^{2}$ transect with a $15 \mathrm{~m} \ell$ syringe. Sediment chlorophyll $a$ was extracted from the top $1.5 \mathrm{~cm}$ of sediment in the same way as the water column chlorophyll $a$.

\section{Pesticide analyses}

Insecticides associated with suspended particles were accumulated continuously by a suspended-particle sampler, from which samples were collected every 2 to 3 weeks. The suspended-particle sampler consisted of a plastic container $(500 \mathrm{~m} \ell)$ with a screw-on lid pierced in the centre by a hole $20 \mathrm{~mm}$ in diameter and an open glass jar suspended directly under the hole in the lid. The samplers were attached approximately $50 \mathrm{~mm}$ above the river bed to a metal stake fixed into the sediment.

Suspended particles were extracted twice with methanol and concentrated using C18 columns. Insecticides were eluted with hexane and dichlormethane and analysed at the Forensic Chemistry Laboratory, Department of National Health, Cape Town. Measurements were made with gas chromatographs (Hewlett-Packard 5890, Avondale, PA, USA) fitted with standard Hewlett-Packard electron-capture, nitrogen phosphorus and flame-photometric detectors, with a quantification limit of $0.1 \mu \mathrm{g} / \mathrm{kg}$ and overall mean recoveries between 79 and 106\% (Schulz et al., 2001). Further details of extraction and analysis of pesticides is described in Schulz et al. (2001). 


\begin{tabular}{|c|c|c|c|}
\hline \multicolumn{4}{|c|}{$\begin{array}{c}\text { Table 1 } \\
\text { Mean ( } \pm \text { standard error) physicochemical parameters measured in the } \\
\text { Rooiels and Lourens estuaries from September } 2001 \text { to March } 2003 \\
(n=44) . \text { Asterisks indicate significant differences between the } \\
\left.2 \text { estuaries }\left({ }^{*} p<0.05 ;{ }^{* *} p<0.01 ;{ }^{* * *} p<0.001\right)\right)\end{array}$} \\
\hline & Unit & $\begin{array}{c}\text { Lourens River } \\
\text { estuary }\end{array}$ & $\begin{array}{c}\text { Rooiels River } \\
\text { estuary }\end{array}$ \\
\hline Outflow & $\mathrm{m}^{3} / \mathrm{sec}$ & $1.00 \pm 1.15$ & $0.46 \pm 0.19$ \\
\hline Mean depth *** & $\mathrm{m}$ & $0.51 \pm 0.18$ & $1.07 \pm 0.14$ \\
\hline Salinity (surface) ${ }^{* * *}$ & $\mathrm{~g} / \mathrm{kg}$ & $1.69 \pm 2.07$ & $5.19 \pm 5.74$ \\
\hline Salinity (bottom)*** & $\mathrm{g} / \mathrm{kg}$ & $6.29 \pm 8.18$ & $19.5 \pm 11.6$ \\
\hline Temperature (surface) $)^{* * *}$ & ${ }^{\circ} \mathrm{C}$ & $19.2 \pm 4.4$ & $18.0 \pm 4.2$ \\
\hline Temperature (bottom) $* * *$ & ${ }^{\circ} \mathrm{C}$ & $19.4 \pm 4.4$ & $16.8 \pm 3.3$ \\
\hline Nitrate*** & $\mathrm{mg} / \ell$ & $3.5 \pm 3.4$ & $0.00 \pm 0.00$ \\
\hline Nitrite* & $\mathrm{mg} / \ell$ & $0.077 \pm 0.124$ & $0.003 \pm 0.006$ \\
\hline Ammonia & $\mathrm{mg} / \ell$ & $0.007 \pm 0.013$ & $0.01 \pm 0.02$ \\
\hline Ortho-phosphate* & $\mathrm{mg} / \ell$ & $0.39 \pm 0.32$ & $0.17 \pm 0.25$ \\
\hline Oxygen (surface) & $\mathrm{mg} / \ell$ & $9.33 \pm 1.88$ & $8.75 \pm 1.28$ \\
\hline Oxygen (bottom)* & $\mathrm{mg} / \ell$ & $8.80 \pm 2.00$ & $7.75 \pm 1.01$ \\
\hline $\mathrm{pH}^{* * *}$ & & $7.6 \pm 0.5$ & $6.7 \pm 1.00$ \\
\hline Total suspended solids*** & $\mathrm{mg} / \ell$ & $63.9 \pm 39.6$ & $1.03 \pm 1.21$ \\
\hline Total organic carbon & $\%$ & $1.29 \pm 0.62$ & $1.29 \pm 0.54$ \\
\hline Grain size** & $\mu \mathrm{m}$ & $164 \pm 79.9$ & $239 \pm 30.1$ \\
\hline Chlorophyll $a$ (water) $^{* *}$ & $\mathrm{mg} / \ell$ & $3.76 \pm 3.98$ & $0.39 \pm 0.46$ \\
\hline Chlorophyll $a$ (sediment)** & $\mathrm{mg} / \ell$ & $8.98 \pm 8.45$ & $2.29 \pm 1.75$ \\
\hline
\end{tabular}

2003). Redundancy analysis was performed separately for the 2 estuaries.

The differences in community composition between the Lourens and Rooiels Estuaries were visualised by principal response curves (PRC) (Van den Brink and Ter Braak, 1999) using the CANOCO software package Version 4.5. The PRC is based on the RDA ordination technique, a constrained form of PCA. The analysis results in a diagram showing the first principal component of the differences in community structure on the y-axis and deviations in time between the 2 sites on the $\mathrm{x}$-axis, with the Rooiels Estuary as reference. The species weights are shown in a separate diagram, and indicate the affinity each has with the major determinant indicated. The species with high positive weights show responses similar to those indicated by the PRC; those with negative weights, show responses opposite to the response indicated by PRC. Species with nearzero weight show a response very dissimilar to the response indicated by PRC, or no response at all.

The data sets of the physicochemical variables and pesticides were tested for significant differences between the 2 estuaries using the student t-test and were also analysed using PRC. In these analyses the variables were centred and standardised before analysis to account for differences in measurement scale (Kersting and Van den Brink, 1997). Guidance

\section{Meiobenthic sampling and community analysis}

The sampling approach attempted to reduce the sampling error caused by small-scale variability in the sediments (Livingston, 1987) and to sample the organisms living in the flocculent layer between the sediment and overlying water column. An area of $10 \mathrm{~m}$ x $300 \mathrm{~mm}$ was actively sampled just above the bottom using a zooplankton net of $63 \mu \mathrm{m}$ mesh size. Four replicates were collected and within each replicate the zooplanktonic and meiobenthic organisms were identified to the lowest possible taxonomic level. Estimates of abundance were based on 8 sub-samples in a matrix box with 64 chambers, of which 8 chambers were randomly selected for identification and counting of all organisms. To assess temporal and spatial patterns of benthic faunal assemblages, the community metrics density (number of individuals $/ \mathrm{m}^{3}$ ), number of taxa, and $\mathrm{H}^{\prime}$ diversity (Shannon and Wiener, 1948) were calculated.

\section{Statistics}

Multivariate techniques are often used to link field concentrations of chemicals and other environmental parameters with invertebrate responses (Leps and Smilauer, 2003). In this study ordination methods were used for dimension reduction, i.e. to reduce the data set to a 2-dimensional summary, which can be presented as an ordination diagram. In this way a graphical summary of the data set is obtained. Redundancy analysis (RDA) is the direct form of principal component analysis (PCA) that focuses the analysis on that particular part of the variance that is explained by external explanatory variables. The significance of the environmental variables was evaluated using Monte Carlo permutation tests (Van den Brink et al., on the use of PRC to analyse monitoring data is described in Van den Brink et al. (2009).

\section{Results}

\section{Temporal and spatial comparison of environmental variables and particle- associated pesticides}

Due to the different type and size of catchment, the magnitudes of many environmental variables differed significantly between the 2 estuaries (Table 1). The most significant differences $(p<0.001)$ were for depth, salinity, temperature, nitrate, $\mathrm{pH}$ and TSS. In general, the Lourens Estuary is a shallower system when compared to the Rooiels $(0.51 \pm 0.18 \mathrm{~m}$ compared to $1.07 \pm 0.14 \mathrm{~m})$, with lower salinities in the bottom $(6.29 \pm 8.18$ compared to $19.5 \pm 11.6)$ and surface waters $(1.69 \pm 2.07 \mathrm{com}-$ pared to $5.19 \pm 5.74)$. Both bottom $\left(19.4 \pm 4.43^{\circ} \mathrm{C}\right)$ and surface temperatures $\left(19.2 \pm 4.44^{\circ} \mathrm{C}\right)$ were higher in the Lourens than in the Rooiels $\left(18.0 \pm 4.20^{\circ} \mathrm{C}\right.$ and $16.8 \pm 3.30^{\circ} \mathrm{C}$, respectively). The water contained significantly more total suspended solids in the Lourens $(63.9 \pm 39.6 \mathrm{mg} / \ell)$ than in the Rooiels $(1.03 \pm$ $1.21 \mathrm{mg} / \ell$ ), and the $\mathrm{pH}$ was significantly higher in the Lourens than in the Rooiels Estuary.

As a result of anthropogenic inputs, nitrate, nitrite and orthophosphate concentrations were significantly higher in the Lourens than the Rooiels Estuary $(p<0.01)$, as was phytoplankton biomass measured as chlorophyll $a$ concentrations in the water column $(3.76 \pm 3.98 \mathrm{mg} / \ell$ compared to $0.39 \pm$ $0.46 \mathrm{mg} / \ell)$ and sediment $\left(8.98 \pm 8.45 \mathrm{mg} / \mathrm{m}^{2}\right.$ compared to $\left.2.29 \pm 1.75 \mathrm{mg} / \mathrm{m}^{2}\right)$.

Cypermethrin (CYP), fenvalerate (FEN), endosulfan total (END), p,p-DDE, chlorpyrifos (CPFS) and prothiofos (PTF) 

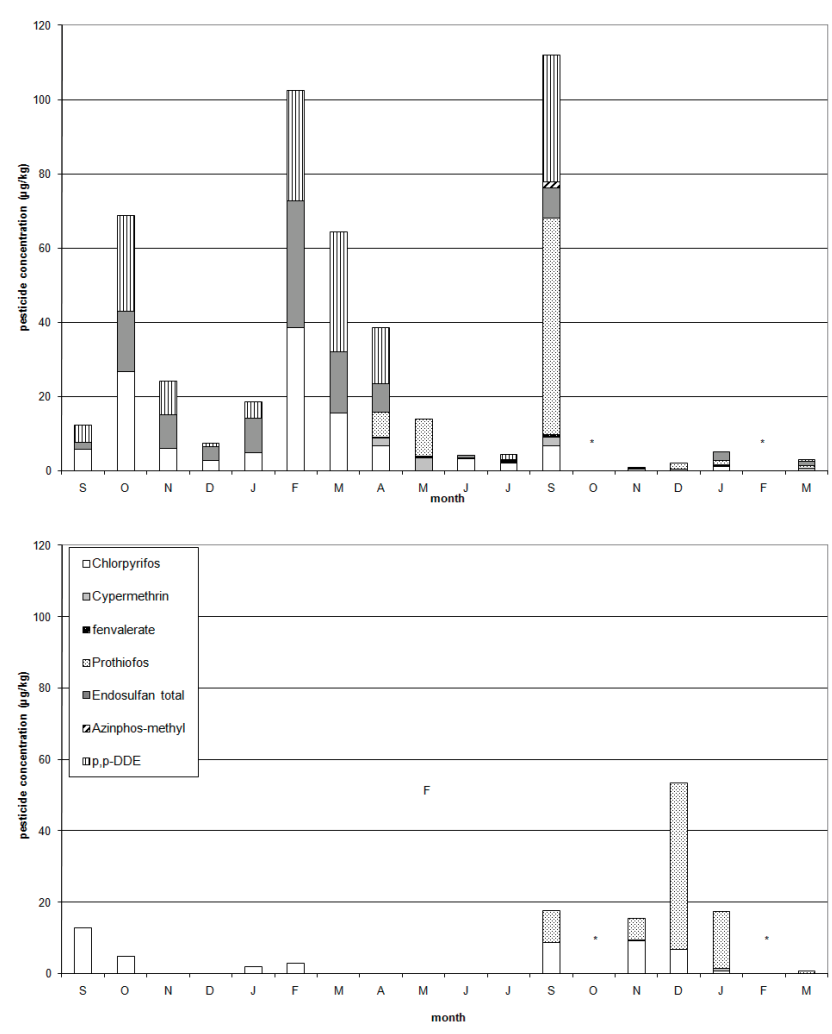

Figure 3

Monthly composition of particle-bound pesticide concentrations detected at Lourens and Rooiels estuaries from September 2001 to March 2003. Asterisks indicate that no samples were collected.

were found in varying concentrations during almost all months within the Lourens Estuary (Table 2, Fig. 3), with the highest concentrations occurring during spring (SeptemberNovember) and autumn (March-May). Despite the absence of agricultural activities in the catchment of the Rooiels, chlorpyrifos, PTF and CYP were frequently detected. The highest concentrations occurred during the summer months (November-January) and PTF concentrations were even higher than those in the Lourens Estuary (Table 2, Fig. 3). However, concentrations of FEN, total - END, p,p-DDE and azinphos-methyl (AZPM) were found to be significantly higher in the Lourens Estuary.

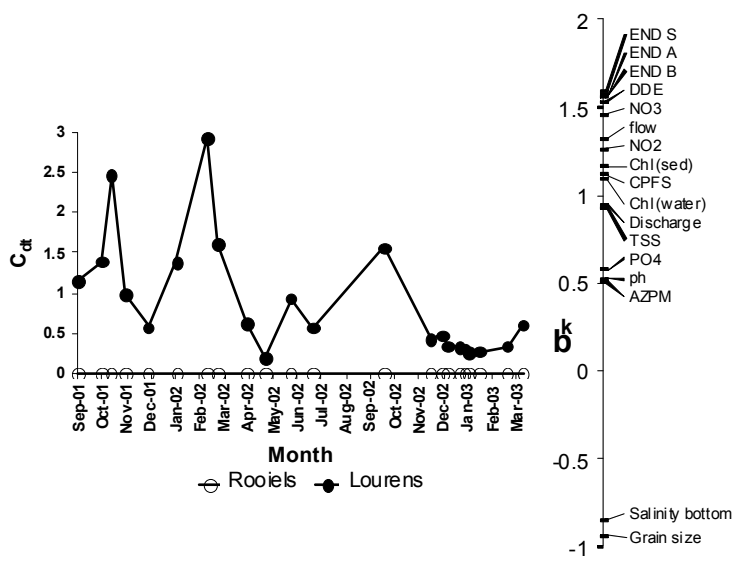

Figure 4

Diagram showing the first component of the PRC of the differences in measured environmental variables and pesticides between Lourens and Rooiels River estuaries. Forty-two percent of the total variation could be attributed to differences between sampling dates, and the other $58 \%$ to differences between the estuaries; $43 \%$ of the latter are displayed in the diagram.

The parameter weights shown in the right part of the diagram represent the affinity of each parameter with the response shown in the diagram. For clarity, only parameters with a weight $>0.5$ or $<-0.5$ are shown.

In the Lourens River PTF ( $34 \mu \mathrm{g} / \mathrm{kg})$ occurred in the highest concentrations, followed by p,p-DDE $(31.0 \mu \mathrm{g} / \mathrm{kg})$, CPFS $(19.6 \mu \mathrm{g} / \mathrm{kg})$, total - END $(18.6 \mu \mathrm{g} / \mathrm{kg})$, CYP $(2.84 \mu \mathrm{g} / \mathrm{kg})$ and fenvalerate $(0.64 \mu \mathrm{g} / \mathrm{kg})$ (Table 2). Cypermethrin $(92 \%)$ and CPFS (92\%) were most frequently detected, followed by total - END (86\%) and PTF (85\%). In the Rooiels Estuary concentrations of PTF $(22.0 \mu \mathrm{g} / \mathrm{kg})$ were highest, followed by CPFS $(8.9 \mu \mathrm{g} / \mathrm{kg})$ and CYP $(0.42 \mu \mathrm{g} / \mathrm{kg})$. Chlorpyrifos showed the highest frequency of detection (50\%), followed by PTF(39\%) and CYP $(23 \%)$.

The PRC diagram (Fig. 4) indicates differences in environmental variables and particle-bound pesticide concentrations between the 2 estuaries and their importance in contributing to the overall differences between them. There is high temporal variability, with $42 \%$ of the variation being attributable to differences between sampling dates. Spatial differences that were not linked to temporal variability explained $58 \%$ of the variation. Variables that contributed most to the differences between the estuaries were higher concentrations of END, p,p-DDE and

\begin{tabular}{|c|c|c|c|c|c|c|}
\hline \multicolumn{7}{|c|}{$\begin{array}{c}\text { Table } 2 \\
\text { Mean }( \pm \text { standard error) concentrations }(\mu \mathrm{g} / \mathrm{kg}) \text { of particle-bound pesticides in the Lourens and } \\
\text { Rooiels estuaries and } 90^{\text {th }} \text { percentile from September to March } 2003(\mathrm{n}=27) \text {. Asterisks indicate } \\
\text { significant differences between the } 2 \text { estuaries }\left({ }^{*} p<0.05 ;{ }^{* *} p<0.01\right)\end{array}$} \\
\hline & \multicolumn{3}{|c|}{\begin{tabular}{|c|} 
Lourens Estuary \\
\end{tabular}} & \multicolumn{3}{|c|}{\begin{tabular}{|l|} 
Rooiels Estuary \\
\end{tabular}} \\
\hline & Mean & $\begin{array}{c}\% \text { of } \\
\text { detection }\end{array}$ & $\begin{array}{c}90^{\text {th }} \\
\text { percentile }\end{array}$ & Mean & $\begin{array}{c}\% \text { of } \\
\text { detection }\end{array}$ & $\begin{array}{c}90^{\text {th }} \\
\text { percentile }\end{array}$ \\
\hline Cypermethrin & $0.92 \pm 1.09$ & 92 & 2.84 & $0.31 \pm 0.84$ & 23 & 0.42 \\
\hline Fenvalerate* & $0.19 \pm 0.22$ & 77 & 0.64 & $0.00 \pm 0.00$ & 0 & 0.00 \\
\hline $\mathrm{DDE}^{* *}$ & $8.42 \pm 13.6$ & 5 & 31.0 & $0.00 \pm 0.00$ & 0 & 0.00 \\
\hline Endosulfan total** & $6.03 \pm 9.40$ & 86 & 18.6 & $0.00 \pm 0.00$ & 0 & 0.00 \\
\hline Azinphos-methyl & $0.07 \pm 0.31$ & 50 & 0.00 & $0.00 \pm 0.00$ & 0 & 0.00 \\
\hline Chlorpyrifos & $7.04 \pm 10.5$ & 92 & 19.6 & $3.21 \pm 5.46$ & 50 & 8.90 \\
\hline Prothiofos & $6.74 \pm 15.8$ & 85 & 34.0 & $12.90 \pm 28.03$ & 39 & 22.0 \\
\hline
\end{tabular}

'Percentage of samples in which the pesticide was detected 


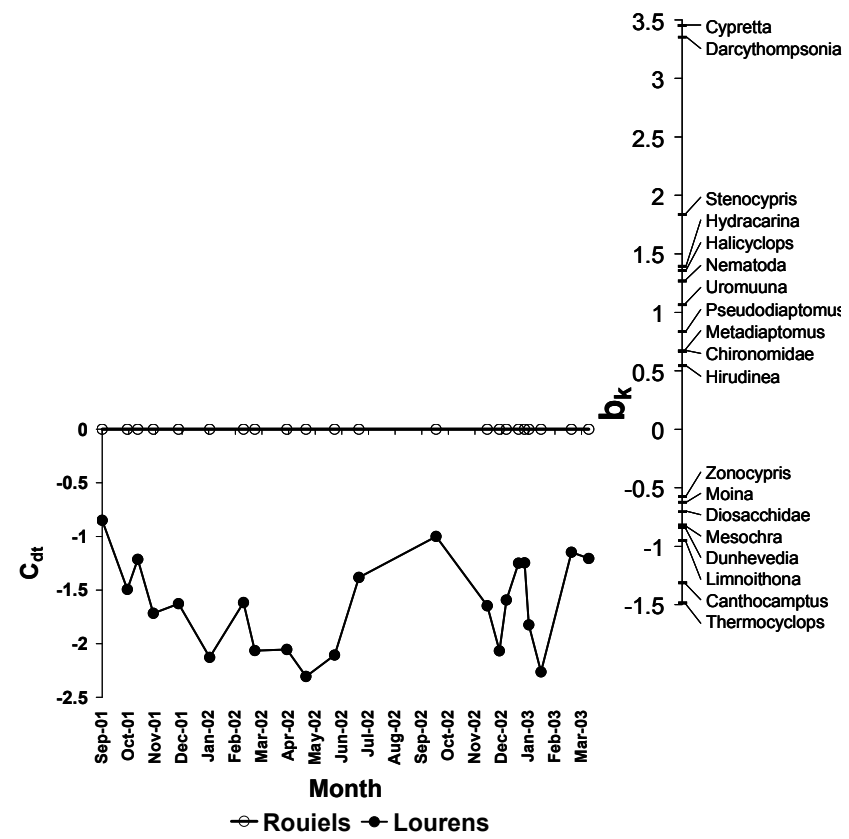

Figure 5

Diagram showing the first component of the PRC of the differences in species composition between the Rooiels and Lourens estuaries. Fifty-two per cent of the total variation in species composition could be attributed to differences between sampling dates, and the other $48 \%$ to differences in species composition between the estuaries; $44 \%$ of the latter are displayed in the diagram. The taxa weights shown in the right part of the diagram represent the affinity of each taxon with the response shown in the diagram. For clarity, only species with a weight $>0.5$ or $<-0.5$ are shown.

nitrates in the Lourens and larger grain size and higher salinity at the bottom of the Rooiels. Flow, nitrite, CPFS and chlorophyll were also important variables contributing to differences between the 2 estuaries.

\section{Temporal and spatial comparison of meiofauna communities}

In general the meiofaunal community in the Rooiels Estuary showed a significantly higher number of taxa $(p<0.001)$, a significantly higher Shannon Wiener Diversity Index $(p<0.001)$ and a generally lower abundance, with less variability over time, than the Lourens Estuary (Table 3). The PRC analysis (Fig. 5) indicated that the 2 community structures were very different from one another; $52 \%$ of the difference was explained by temporal differences and $48 \%$ by differences between the 2 estuaries. Differences in the fauna were explained mostly by more Cypretta and Darcythompsonia in the Rooiels, and more Thermocyclops and Canthocamptus in

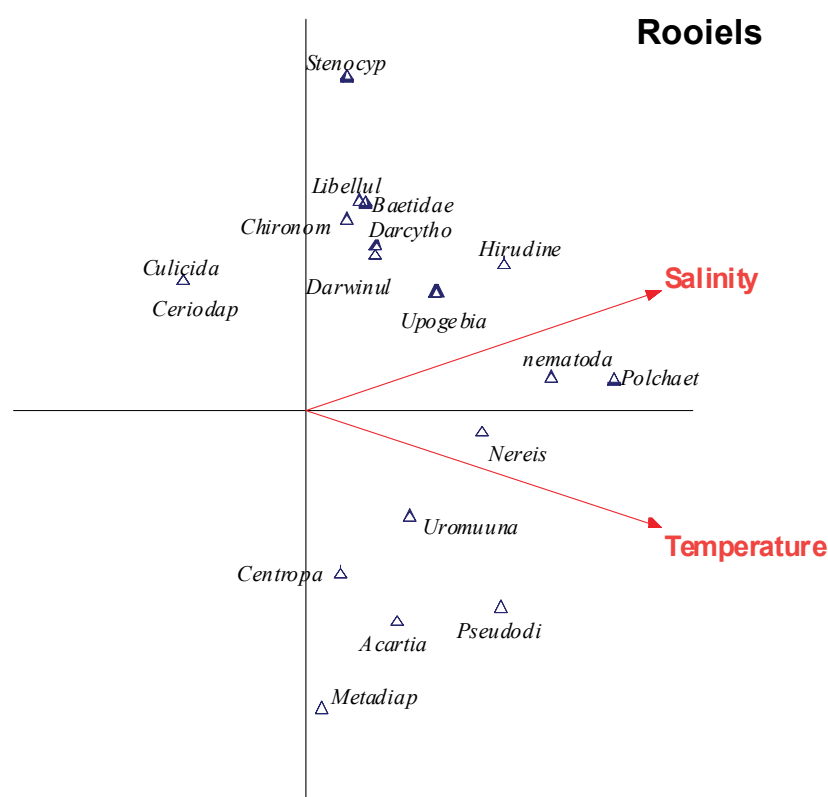

Figure 6

$R D A$ triplot resulting from an analysis using the environmental variables and pesticide concentrations that explain a significant part of the seasonal variation in the species composition in the Rooiels Estuary as explanatory variables and meiofauna taxa composition as taxa data. The 2 significant variables explain $14 \%$ of the seasonal variation in species composition, of which

$71 \%$ is displayed on the first axis and another $29 \%$ on the second axis. For clarity only the 18 most important taxa out of 45 are shown.

the Lourens. Overall the difference is attributable to the greater number of species in the Rooiels Estuary, which correlates with the higher diversity index (Table 3).

\section{The meiofaunal community and its driving variables}

Within the RDA biplot the most important taxa and significant environmental variables are shown in Figs. 6 and 7. The variables explaining a significantly part (14\%) of the seasonal variation in invertebrate abundance in the Rooiels Estuary were salinity and temperature (Fig. 6). The RDA indicated that the abundance of most of the taxa were increasing with higher salinity and temperatures and taxa such as Upogebia, Nereis, Uroma and the nematodes were positively correlated with salinity and temperature.

The meiofaunal community in the Lourens Estuary is significantly influenced by a number of variables that are probably the result of anthropogenic impacts (Fig. 7). The variables explaining a significant part of the variance in the dataset (43\%) were salinity and temperature, CPFS, nitrate and flow. Mesochra decreased with higher CPFS and nitrate concentrations, and increased with higher salinity and temperature.

Table 3

Mean ( \pm standard error) number of taxa, total abundance and Shannon Wiener Diversity Index in the Lourens and Rooiels estuaries and $90^{\text {th }}$ percentile from September to March 2003 $(n=27)$. Asterisks indicate where there are significant differences $(p<0.001)$ between the 2 estuaries.

\begin{tabular}{|c|c|c|c|c|}
\hline & \multicolumn{2}{|c|}{ Lourens Estuary } & \multicolumn{2}{|c|}{ Rooiels Estuary } \\
\hline & Mean & $90^{\text {th }}$ percentile & Mean & $90^{\text {th }}$ percentile \\
\hline Number of $\operatorname{taxa} * * * / \mathrm{m}^{3}$ & $6.8 \pm 2.7$ & 10 & $10.3 \pm 2.7$ & 14 \\
\hline Total abundance $/ \mathrm{m}^{3}$ & $6600 \pm 12391$ & 16423 & $2442 \pm 1318$ & 3951 \\
\hline Shannon Diversity Index ${ }^{* * *}$ & $1.1 \pm 0.4$ & 1.6 & $1.6 \pm 0.3$ & 1.9 \\
\hline
\end{tabular}




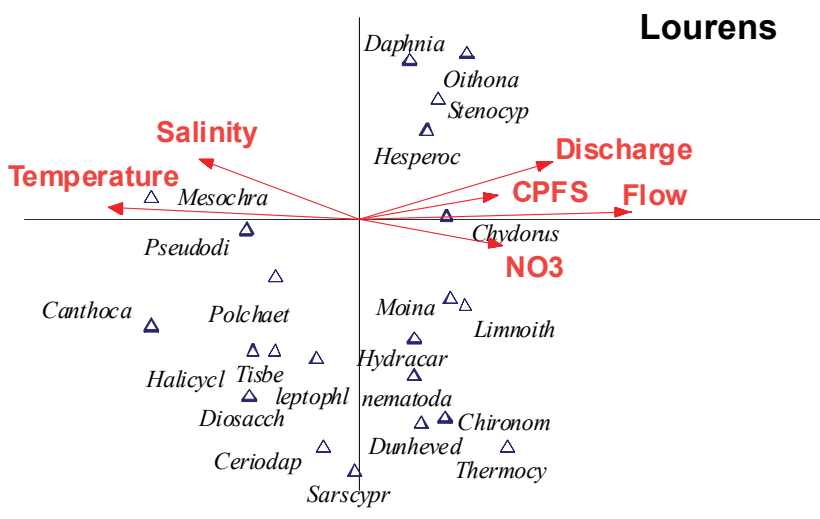

Figure 7

RDA triplot resulting from an analysis using the environmental variables and pesticide concentrations that explain a significant part of the seasonal variation in the species composition in the Lourens Estuary as explanatory variables and meiofauna taxa composition as taxa data. The 6 significant variables explain $43 \%$ of the seasonal variation in species composition, of which $69 \%$ are displayed on the first axis and another $12 \%$ on the second axis. For clarity only the 20 most important taxa out of 45 are shown.

Furthermore, the taxa Pseudodiaptomus, Canthocamptus and polychaetes were negatively correlated with CPFS and nitrate concentrations. In general, oligohaline taxa (e.g. Moina and Limnoithona) decreased in abundance at higher salinities.

\section{Discussion}

\section{Temporal and spatial comparison of environmental variables and particle-associated pesticides}

Due to a lack of agricultural and urbanisation influences in its catchment the Rooiels Estuary is more pristine than the Lourens River, with lower particle-bound pesticide concentrations and also lower nutrient concentrations resulting in lower chlorophyll $a$ values. The lower MAR in the Rooiels Estuary results in a more saline environment with evident stratification in salinity, temperature and oxygen and with higher salinity and lower oxygen values in bottom waters, a typical feature for natural, relatively deep TOCEs during the dry season (Kibirige and Perissinotto, 2003)

Despite the fact that no agricultural activities are documented for its catchment, pesticides such as CPFS, PTF and CYP were sometimes recorded in the Rooiels, particularly during the 2003 summer when concentrations were actually higher than those in the Lourens. The input of pesticides to the Rooiels Estuary could originate from one or more of the following sources:

Studies have shown that volatilisation can cause off-site movement of pesticides via atmospheric transport and subsequent contamination of surface waters (Harman-Fetcho et al., 2000; LeNoir et al., 1999). The Western Cape climate is characterised by strong south-easterly winds during summer with wind directions from agricultural activities southeast towards the Rooiels Estuary. Most pesticide application using mist-blow techniques occurs during the summer season (Schulz, 2001), which also coincides with the period of high concentrations found in the estuary. However, high mountains (Hottentots Holland Mountain) are situated between the 2 catchments, which could serve as a partial barrier for atmospheric pesticide transport. Additionally it is puzzling why endosulfan was not found in the Rooiels Estuary, since it is also heavily applied during the summer season. Due to the south-easterly wind direction, the current within False Bay is directed from the Lourens and other estuaries with 'agricultural' catchments towards the Rooiels Estuary (Taljaard et al., 2000). Particle-bound pesticides with a high $K_{o c}$ and low solubility (as prothiofos, CPF and cypermethrin) could be transported by the currents in False Bay and enter the Rooiels Estuary on the incoming tide. However, pesticides tend to bind to particles which in turn are likely to settle either within the estuary (Bollmohr et al., 2009c) or within the bay. Additionally it is hard to explain why p,p-DDE, which is present in high concentrations in the Lourens River, and has the highest $K_{o c}$ and the longest $D T_{50}$, has not been detected in the Rooiels Estuary.

Residential areas are situated on the southern side of the estuary and the houses are mainly occupied during the holidays (Heydorn and Grindley, 1982). The primary holiday period occurs during summer (December and January), which coincides with the time when high pesticide concentrations were found. Many household products contain CPFS and CYP.

Bollmohr et al. (2007) ranked the pesticide concentrations detected in the Lourens River in terms of their risk towards the environment, by comparing these with various effect concentrations (Chandler and Green, 2001; Chandler et al., 1994; Leonard et al., 2001). Chlorpyrifos and total-END posed the highest risk towards both freshwater and marine communities in the Lourens Estuary. Within the Rooiels Estuary there is a possibility that CPF may pose a risk towards harpacticoid species during certain summer months (Bollmohr et al., 2009b; Chandler and Green, 2001). Toxicity data and threshold values for PTF are inadequate; therefore it is not possible to assess a probable risk for this pesticide towards the aquatic environment in either estuary.

\section{Temporal and spatial comparison of meiofaunal communities}

The prolonged period of mouth closure that most TOCEs experience generally leads to low levels of taxonomic diversity (Perissinotto et al., 2000). Hartwell and Clafin (2005) classified a Shannon Wiener Index of $<1.5$ for macrobenthos in permanently open estuaries as 'low', and above 2.4 as 'high', while a Shannon Wiener index for zooplankton in the impacted, temporarily-open Mpenjati Estuary ranged between only 1.0 and 1.20 (Kibirige and Perissinotto, 2003). Although the Lourens Estuary supports more freshwater species than the Rooiels (Bollmohr et al., 2009c) due to a higher MAR, overall meiofaunal diversity is lower than in the Rooiels, which is characterised by a greater number of taxa, most of which are of marine or estuarine origin. The higher meiofaunal abundance in the Lourens Estuary can be explained by the higher organic input arising from a greater MAR when compared to the Rooiels. The lower variability in meiofaunal abundance in the Rooiels Estuary is probably a result of the more stable estuarine environment when compared to the Lourens.

Species contributing most to spatial differences were the ostracod Cypretta and harpacticoid copepod Darcythompsonia for the Rooiels Estuary (with the highest positive weighting), and Thermocyclops and Canthocamptus for the Lourens Estuary (with the highest negative weighting). Ostracods are mainly influenced by temperature, salinity, depth and grain size (Curry, 1999), and sewage pollution as a result of low oxygen (Mezquita et al., 1999). Based on toxicity data they are not significantly more sensitive to pollution than other crustaceans 
(Sanchez-Bayo, 2006) but have a slower recovery rate after pollution events (Dernie et al., 2003). The combination of low oxygen, salinity, low grain size (mud), higher temperature and more frequent pesticide concentrations might, however, have resulted in the loss of ostracods from the Lourens Estuary. No information is available on the harpacticoid genus Darcythompsonia and further work on the sensitivity of this genus is required. Thermocyclops and Canthocamptus are known as freshwater and/or estuarine species and might have been carried into the Lourens Estuary from upstream, whereas the salinity in the Rooiels Estuary might have been too high for these taxa to survive. Insufficient toxicity data are available for these genera to reach conclusions regarding the causality of the correlations of their abundances with the pesticide levels in either estuary.

\section{The meiofaunal community and its driving variables}

The RDA analysis identified salinity and temperature as the only significant variables driving meiofaunal community structure in the Rooiels Estuary. These variables have been identified as the most important for natural estuarine systems by various other authors (e.g. Austen, 1989; Willmer et al., 2000; Nozais et al., 2005). Grain size and water depth are often regarded as primary variables in determining aspects of community structure in meiobenthic organisms (Soetaert et al., 1994; Curry, 1999; Sherman and Coull, 1980), but these variables showed little variation within the Rooiels Estuary.

The community structure of the Lourens Estuary is, however, significantly influenced by a number of variables, including salinity, temperature, flow and anthropogenic stressors such as nitrate and CPFS. The above result suggests interactions between the effects of both natural and anthropogenic drivers on the meiofaunal community. The abundance of the genus Mesochra, as an example, increased with decreasing CPFS concentrations and increasing salinity. A microcosm toxicity test on intact estuarine sediment with the marine copepod Amphiascus tenuiremis, by Chandler et al. (1997), showed acute effects after $96 \mathrm{~h}$ at CPFS levels ranging from 21 to $33 \mu \mathrm{g} / \mathrm{kg}$. A related study by Chandler and Green (2001) found that chronic full-life-cycle exposures to concentrations of 11 to $22 \mu \mathrm{g} / \mathrm{kg}$ sediment-associated CPF resulted in consistently significant reductions in production of copepodites and nauplii by $A$. tenuiremis. These concentrations were exceeded by the $90^{\text {th }}$ percentile found in the Lourens Estuary $(19.6 \mu \mathrm{g} / \mathrm{kg})$. A laboratory study by Bollmohr et al. (2009b) indicated that exposure to CPFS of 5.9 to $6.4 \mu \mathrm{g} / \mathrm{kg}$, which was exceeded on $37 \%$ of the sampling occasions during the current field programme, was detrimental to the survival of Mesochra parva. The above laboratory study also revealed that $M$. parva survival decreased by 60 to $90 \%$ due to CPFS exposure and increased by 10 to $50 \%$ as salinity increased from 3 to 15 .

The frequency of occurrence and mean concentration of CPFS in the Rooiels Estuary (FO $=50 \%$ of samples, mean concentration $=3.21 \pm 5.46 \mu \mathrm{g} / \mathrm{kg}$ ) was very different to the frequency of occurrence and mean concentration of CPFS in the Lourens Estuary ( $\mathrm{FO}=92 \%$ of samples, mean concentration $=7.04 \pm 10.5 \mu \mathrm{g} / \mathrm{kg}$ ). These results clearly indicate an elevated and more prolonged pollution problem in the Lourens when compared to the Rooiels system. However, more work is required to understand the response of various meiofaunal taxa to this pollutant under different salinity conditions.

\section{References}

ADAMS JB, BATE GC, HARRISON TD, HUIZINGA P, TALJAARD $S$, VAN NIEKERK L, PLUMSTEAD EE, WHITFIELD AK and WOOLDRIDGE TH (2002) A method to assess the freshwater inflow requirements of estuaries and application to the Mtata estuary, South Africa. Estuar. Coast. Shelf Sci. 25 1382-1393.

ASTM (2000) Standard Test Methods for Moisture, Ash and Organic Matter of Peat and Other Organic Soils. Method D 2974-00. American Society for Testing and Materials. West Conshohocken, PA.

AUSTEN MC (1989) Factors affecting estuarine meiobenthic assemblage structure: a multifactoria; microcosm experiment. J. Exp. Mar. Biol. Ecol. 130 167-187.

BOLLMOHR S, VAN DEN BRINK PJ, WADE PW, DAY JA and SCHULZ R (2009) Spatial and temporal variability in particlebound pesticide exposure and their effects on benthic communities structure in a temporarily open estuary. Estuar. Coast. Shelf Sci. 82 50-60.

BOLLMOHR S and SCHULZ R (2008) Seasonal changes of macroinvertebrate community in a Western Cape River receiving nonpointsource insecticide pollution. Environ. Toxicol. Chem. 28 809-817.

BOLLMOHR S, DAY JA and SCHULZ R (2007) Temporal variability in particle-bound pesticide exposure in a temporarily open estuary, South Africa. Chemosphere 68 479-488.

BOLLMOHR S, HAHN T and SCHULZ R (2008) Interactive effect of salinity decrease, salinity adaptation and chlorpyrifos exposure on an estuarine harpacticoid copepod, Mesochra parva, in South Africa. Ecotoxicol. Environ. Saf. 72 756-764.

CHANDLER GT, COULL BC, SCHIZAS NV and DONELAN TL (1997) A culture-based assessment of the effects of chlorpyrifos on multiple meiobenthic copepods using microcosms of intact estuarine sediments. Environ. Toxicol. Chem. 16 2339-2346.

CHANDLER GT and GREEN AS (2001) Developmental stage specific life-cycle bioassay for assessment of sediment-associated toxicant effects on benthic copepod production. Environ. Toxicol. Chem. 20 171-178.

CLIFF S and GRINDLEY JR (1982) Report No.17 Lourens (CSW7). In: Heydorn AEF and Grindley JR (eds.) Estuaries of the Cape (Part 2) Synopsis of Available Information on Individual Systems. CSIR Report No. 416. CSIR, Stellenbosch, South Africa. 39 pp.

CURRY BB (1999) An environmental tolerance index for ostracodes as indicators of physical and chemical factors in aquatic habitats. Palaeogeogr. Palaecol. 148 51-63.

DABROWSKI JM, PEALL SKC, REINECKE AJ, LIESS M and SCHULZ R (2002) Runoff -related pesticide input into the Lourens River, South Africa: basic data for the exposure assessment and risk mitigation at the catchment scale. Water Air Soil Pollut. 135 265-283.

DECHO AW and CASTENHOLZ RW (1986) Spatial patterns and feeding of meiobenthic harpactiocid copepods in relation to resident microbial flora. Hydrobiol. 131 87-96.

DERNIE KM, KAISER MJ, RICHARDSON EA and WARWICK RM (2003) Recovery of soft sediment communities and habitats following physical disturbance. J. Exp. Mar. Biol. Ecol. 285-286 415-434.

DEN BESTEN PJ and VAN DEN BRINK PJ (2005) Bioassay response and effects on benthos after pilot remediations in the delta of the rivers Rhine and Meuse. Environ. Pollut. 136 197-208.

FOFONOFF TL and MILLARD JR RC (1983) Algorithms for computation of fundamental properties of seawater. UNESCO Technical papers in marine science No. 44.

HARMAN-FETCHO JA, McCONELL LL, RICE CP and BAKER JE (2000) Wet deposition and air-water gas exchange of currently used pesticides to a subestuary of the Chesapeake Bay. Environ. Sci. Technol. 34 1462-1468.

HARTWELL SI and CLAFIN LW (2005) Cluster analysis of contaminated sediment data: Nodal analysis. Environ. Toxicol. Chem. 24 1816-1834.

HEYDORN AEF and GRINDLEY JR (1982) Estuaries of the Cape, Part II. Synopses of Available Information on Individual Systems. Report No. 7: Gamtoos (CMS48). CSIR Research Report No. 406. 
HILMER T (1990) Factors Influencing the Estimation of Primary Production in Small Estuaries. Ph.D. Thesis, University of Port Elizabeth, South Africa.

JAMES NC, WHITFIELD AK and COWLEY PD (2008) Long-term stability of the fish assemblages in a warm-temperate South African estuary. Estuar. Coast. Shelf Sci. 76 723-738.

KERSTING K and VAN DEN BRINK PJ (1997) Effects of the insecticide Dursban4E (active ingredient chlorpyrifos) in outdoor experimental ditches: responses of ecosystem metabolism. Environ. Toxicol. Chem. 16 251-259.

KIBIRIGE I and PERISSINOTTO R (2003) The zooplankton community of the Mpenjati Estuary, a South African temporarily open/ closed system. Estuar. Coast. Shelf Sci. 58 727-741.

LENOIR JS, MCCONNELL LL, FELLERS GM, CAHILL TM and SEIBER JN (1999) Summertime transport of current-use pesticides from California's central valley to the Sierra Nevada Mountain Range, USA. Environ. Toxicol. Chem. 18 2715-2722.

LEPS J and SMILAUER P (2003) Multivariate Analysis of Ecological Data using Canoco. Cambridge University Press, Cambridge, UK. $269 \mathrm{p}$.

LEONARD AW, HYNE RV, LIM RP, LEIGH KA, LE J and BECKETT R (2001) Fate and toxicity of endosulfan in Naomi River Water and Bottom Sediment. J. Environ. Qual. 30 750-759.

MEZQUITA F, HERNANDEZ JR and RUEDA J (1999) Ecology and distribution of ostracods in a polluted Mediterranean river. Palaeogeogr. Palaecol. 148 87-103.

MILIOU H (1993) Temperature, salinity and light induced variations on larval survival and sex ration of Tisbe holothuriae Humes (Copepoda: Harpactiocida). J. Exp. Mar. Biol. Ecol. 173 95-109.

NOZAIS C, PERISSINOTTO R and TITA G (2005) Seasonal dynamics of meiofauna in a South African temporarily open/closed estuary (Mdloti Estuary, Indian Ocean). Estuar. Coast Shelf Sci. 62 325-338.

PERISSINOTTO R, WALKER DR, WEBB P, WOOLDRIDGE TH and BAILEY R (2000) Relationships between zoo- and phytoplankton in a warm temperate, semi-permanently closed estuary, South Africa. Estuar. Coast Shelf Sci. 51 1-11.

PILLAY D and PERISSINOTTO R (2009) Community structure of epibenthic meiofauna in the St. Lucia Estuarine Lake (South Africa) during a drought phase. Estuar. Coast Shelf Sci. 81 94-104.

QUINTINO V, ELLIOT M and RODRIGUES AM (2006) The derivation, performance and role of univariate and multivariate indicators of benthic change: Case studies at differing spatial scales. J. Exp. Mar. Biol. Ecol. 330 368-382.
RANASINGHE R and PATTIARATCHI C (1999) Circulation and mixing characteristics of a seasonally open tidal inlet: a field study. Mar. Freshwater Res. 50 281-290.

SÁNCHEZ-BAYO F (2006) Comparative acute toxicity of organic pollutants and reference values for crustaceans. I. Branchiopoda, Copepoda and Ostracoda. Environ. Pollut. 139 385-420.

SCHULZ R (2001) Rainfall-induced sediment and pesticide input from orchards into the Lourens River, Western Cape, South Africa: importance of a single event. Water Res. 35 1869-1876.

SCHULZ R, PEALL, SKC, DABROWSKI JM and REINECKE AJ (2001) Current-use insecticides, phosphates and suspended solids in the Lourens River, Western Cape, during the first rainfall event of the wet season. Water SA 27 65-70.

SHANNON CE and WIENER N (1948) A mathematical theory of communication. A.T. \& T. Tech. J. 27 379-423.

SHERMAN KM and COULL BC (1980) The response of meiofauna to sediment disturbance. J. Exp. Mar. Biol. Ecol. 45 59-71.

SOETAERT K, VINEX M, WITTOECK J, TULKENS M, VAN GANSBEKE D (1994) Spatial patterns of the Westerschelde meiobenthos. Estuar. Coast. Shelf Sci. 39 367-388.

VAN DEN BRINK PJ and TER BRAAK CJF (1999) Principal response curves: Analysis of time-dependent multivariate responses of a biological community to stress. Environ. Toxicol. Chem. 18 138-148.

VAN DEN BRINK PJ, DEN BESTEN PJ, BIJ DE VAATE A and TER BRAAK CJF (2009) The use of the principal response curves techniques for the analysis of multivariate time series from biomonitoring studies. Environ. Monit. Assess. 152 271-281.

VAN DEN BRINK PJ, VAN DEN BRINK NW and TER BRAAK CJF (2003) Multivariate analysis of ecotoxicological data using ordination: Demonstrations of utility on the basis of various examples. Australas. J. Ecotox. 9 141-156.

WARWICK RM, PLATT HM, CLARKE KR, AGARD J and GOBIN $\mathrm{J}$ (1990) Analysis of macrobenthic and meiobenthic community structure in relation to pollution and disturbance in Hamilton Harbour, Bermuda. J. Exp. Mar. Biol. Ecol. 138 119-142.

WHITFIELD AK (1995) Available Scientific Information on Individual South African Estuarine Systems. WRC Report No. 577/1/95. Water Research Commission, Pretoria, South Africa. 204 pp.

WHITFIELD AK and BATE G (2007) The Freshwater Requirements of Intermittently Open Cape Estuaries. WRC Report No. 1581/1/2007, Pretoria, South Africa.

WILLMER P, STONE G and JOHNSTON I (2000) Environmental Physiology of Animals. Blackwell Science, Oxford, UK. 644 pp.

\begin{tabular}{|c|c|c|c|}
\hline \multicolumn{4}{|c|}{ Appendix 1 Taxon list (average \pm standard deviation) } \\
\hline Taxa & Abbreviation ${ }^{\#}$ & $\begin{array}{l}\text { Lourens River } \\
\text { estuary }(n=31)\end{array}$ & $\begin{array}{l}\text { Rooiels River } \\
\text { estuary }(n=29)\end{array}$ \\
\hline Halicyclops & Halicycl & $51 \pm 122$ & $128 \pm 177$ \\
\hline Thermocyclops & Thermocy & $218 \pm 509$ & $1 \pm 7$ \\
\hline Macrocyclops & & $0 \pm 0$ & $3 \pm 11$ \\
\hline Paracyclops & & $3 \pm 13$ & $0 \pm 0$ \\
\hline Hesperocyclops & Hesperoc & $9 \pm 33$ & $0 \pm 0$ \\
\hline Limnoithona & Limnoith & $53 \pm 155$ & $2 \pm 11$ \\
\hline Oithona & & $3 \pm 12$ & $0 \pm 0$ \\
\hline Smirnoviella & & $1 \pm 6$ & $0 \pm 0$ \\
\hline Acartia & & $5 \pm 28$ & $2 \pm 13$ \\
\hline Pseudiaptomus & Pseudodi & $80 \pm 204$ & $228 \pm 498$ \\
\hline Centropagidae & Centropa & $0 \pm 0$ & $43 \pm 231$ \\
\hline Metadiaptomus & Metadiap & $5 \pm 28$ & $33 \pm 87$ \\
\hline Canthocamptus & Canthoca & $2768 \pm 4326$ & $175 \pm 245$ \\
\hline Darcythompsonia & Darcytho & $0 \pm 0$ & $575 \pm 558$ \\
\hline Mesochra & Mesochra & $9142 \pm 22978$ & $235 \pm 496$ \\
\hline Diosacchidae & Diosacch & $111 \pm 284$ & $0 \pm 0$ \\
\hline Tisbe & Tisbe & $52 \pm 134$ & $0 \pm 0$ \\
\hline
\end{tabular}

Available on website http://www.wrc.org.za 


\begin{tabular}{|l|l|c|c|}
\hline Stenocypris & Stenocyp & $1 \pm 3$ & $104 \pm 181$ \\
\hline Sarscypridopsis & Sarscypr & $11 \pm 24$ & $12 \pm 64$ \\
\hline Darwinula & Darwinul & $0 \pm 0$ & $5 \pm 13$ \\
\hline Zonocypris & & $5 \pm 9$ & $0 \pm 0$ \\
\hline Cypretta & Cypretta & $0 \pm 0$ & $558 \pm 642$ \\
\hline Daphnia & Daphnia & $5 \pm 19$ & $0 \pm 0$ \\
\hline Moina & Moina & $166 \pm 771$ & $0 \pm 0$ \\
\hline Chydorus & Chydorus & $50 \pm 283$ & $0 \pm 0$ \\
\hline Ceriodaphnia & Ceriodap & $52 \pm 224$ & $2 \pm 12$ \\
\hline Dunhevedia & Dunheved & $676 \pm 3662$ & $2 \pm 11$ \\
\hline Hydracarina & & $4 \pm 14$ & $35 \pm 37$ \\
\hline Chironomidae & Chironom & $24 \pm 53$ & $31 \pm 36$ \\
\hline Nereis & & $2 \pm 6$ & $20 \pm 35$ \\
\hline Polchaetlarvae & Polychaet & $10 \pm 24$ & $120 \pm 249$ \\
\hline Uromuuna & Uromuuna & $0 \pm 0$ & $27 \pm 53$ \\
\hline Turbellaria & & $0 \pm 0$ & $4 \pm 12$ \\
\hline Rotifera & & $14 \pm 82$ & $0 \pm 0$ \\
\hline Culicidae & & $0 \pm 2$ & $0 \pm 2$ \\
\hline Oligochaet & & $3 \pm 9$ & $5 \pm 14$ \\
\hline Perlidae & & $1 \pm 3$ & $0 \pm 0$ \\
\hline Baetidae & Baetidae & $6 \pm 15$ & $2 \pm 8$ \\
\hline Leptophlebiidae & Leptophl & $1 \pm 6$ & $2 \pm 11$ \\
\hline Porifera & & $0 \pm 0$ & $5 \pm 18$ \\
\hline Hirudinea & Hirudine & $0 \pm 0$ & $15 \pm 33$ \\
\hline Libellulidae & Libellul & $0 \pm 2$ & $1 \pm 5$ \\
\hline Upogebia & Upogebia & $0 \pm 0$ & $9 \pm 20$ \\
\hline Nematoda & Nemtatoda & $22 \pm 43$ & $143 \pm 170$ \\
\hline Amphipoda & & $0 \pm 0$ & $4 \pm 9$ \\
\hline
\end{tabular}

\#appearing in Figs. 6 and 7 